\title{
The Role of the Vietnam Fatherland Front in Establishing Socialist Democracy in Ho Chi Minh City in Renovation Period
}

\author{
Dinh Van Chi \\ Faculty of Party Building, Ho Chi Minh City Cadre Academy, Ho Chi Minh City, Vietnam
}

Email address:

dinhvanchi84@gmail.com

\section{To cite this article:}

Dinh Van Chi. The Role of the Vietnam Fatherland Front in Establishing Socialist Democracy in Ho Chi Minh City in Renovation Period. International Journal of Philosophy. Vol. 9, No. 3, 2021, pp. 162-168. doi: 10.11648/j.ijp.20210903.17

Received: August 5, 2021; Accepted: August 23, 2021; Published: August 30, 2021

\begin{abstract}
Vietnam Fatherland Front is a political coalition organization representing all classes, social strata, ethnic groups, religions in Vietnam as well as Vietnamese overseas. One of the important tasks of this organization is to bring into full play the people's mastery. The present study aims to analyze the role of the Vietnam Fatherland Front in establishing a socialist democracy in Ho Chi Minh City during the renovation period. Specifically, it examines the situation of promoting the role of The Vietnam Fatherland Front in Ho Chi Minh City in the exercise of the democratic regulations at the grassroots level, contributing to the establishment of socialist democracy in Viet Nam. To obtain the research objectives, the author gives the hypothesis that the Vietnam Fatherland Front in Ho Chi Minh City is the political base of the people's government. It expresses the will, aspiration, and the great unity bloc of the entire people to promote the people's mastery, consult, coordinate and unify the actions of its members, contributing to the establishment of socialist democracy in Ho Chi Minh City. The author has used scientific research methods such as analysis and synthesis, deduction and induction, abstraction and generalization, logic and history, and comparison to come to the findings and recommendations of the study. The results of the study show that the Vietnam Fatherland Front plays a very important role in creating the people's great unity bloc, promoting the people's right to mastery, conducting consultations, and coordinating and unifying actions among its members in the cause of national construction and defense.
\end{abstract}

Keywords: Vietnam Fatherland Front, Socialist Democracy, Ho Chi Minh City, Renovation Period

\section{Introduction}

The People's power in all modern societies can be expressed in two ways: representative democracy and direct democracy, which can be exercised all over the country. The People as the subject of power can empower individuals or organizations to exercise their rights, or they can also express their own will to directly exercise their rights.

In Vietnam, the working people exercise their right to master the society not only through the State but also through the Vietnam Fatherland Front, the Communist Party of Vietnam, and socio-political organizations: Vietnam Labor Union, Ho Chi Minh Communist Youth Union, Farmers' Association, Women's Union, Veterans' Association in which the Vietnam Fatherland Front plays a critical role in promoting democracy, creating the great unity bloc of the whole people to build the country, establish democracy at the grassroots and socialist democracy in the renovation period [1].

The Communist Party of Vietnam always respect the People, highly value the position of the People's power and strives for the People's interests. During the renovation period, the rule of law of the State and socialist democracy have been gradually established and consolidated [2]. The Party has exercised and widely promote socialist democracy and the people's right to mastery, promoting the great strength of national unity, consolidating and raising the People's confidence, and strengthening social consensus. It has also continued to renovate the organization, contents, and methods of the Vietnam Fatherland Front to respond to the current exercise of democracy at the grassroots [3]. Exercising democracy at the grassroots and promoting the 
people's mastery is a great, meaningful, and important motivation for promoting economic, cultural, and social development, and ensuring national defense and security. This has been contributing to the establishment of socialist democracy in the renovation period, thus making a step to penetrate deeply into all areas of the State's activities, into social life in many regions of the country, creating models and examples with pervasive including the most dynamic city in the country - Ho Chi Minh City.

Ho Chi Minh City consists of 16 districts, 5 rural districts, and 1 city. It has 322 commune-level administrative divisions, including 259 wards, 58 communes, and 5 towns [4]. In the process of development and integration, Ho Chi Minh City has always been an economic, financial, commercial, and service center - the nucleus of the Southern economic region, one of the three major economic regions of the country. The role of the Vietnam Fatherland Front has contributed to the establishment of socialist democracy in the entire social life of the city's people in the current renovation period. With the promotion of the role of the Fatherland Front in establishing a socialist democracy, the economic growth rate of Ho Chi Minh City is always high. The city only accounts for $0.6 \%$ of the area and $8.3 \%$ of the population of the whole country, but it has contributed to $22.2 \%$ of the gross national product. Value-added services of the city have accounted for $33 \%$, leading the country. The production index of the whole industry of Ho Chi Minh city increases by $7.7 \%$ /year on average. The agricultural sector of the city has been modernized in the right direction. Labor productivity has been 3 times more than the whole country. The city has attracted big investments in foreign projects. These achievements have been attained because over the years, the Ho Chi Minh City Party Committee and government have deeply realized that in the condition that the ruling Party leads the building of socialism and firmly defends the Fatherland, among the factors contributing to the implementation of these political tasks is the importance of building and promoting the role of the Vietnam Fatherland Front, taking steps to innovate, creating many positive changes in promoting the great national unity bloc, mobilizing the great strength of the whole political system and the people to participate in the victories of the City's important political goals and tasks set out during the term [5]. In recent years, the Vietnam Fatherland Front in Ho Chi Minh city has well promoted its role in establishing democracy at the grassroots through the performance of functions and tasks, resolving relationships with party committees, authorities, and socio-political organizations. It has contributed to the establishment of socialist democracy in Ho Chi Minh City, which is reflected in the democratic and open atmosphere in the implementation of socio-economic, defense, and security goals and tasks of the city in the renovation period.

However, the socio-economic development process has given rise to many new relationships between social classes in Ho Chi Minh City. Many of the Party's lines and policies have been slowly carried out, the great national unity bloc and the relationship between the Party, the government, and the people in the locality have not been very strong and are facing new difficulties. The implementation of the principle of voluntariness, democratic consultation, and coordinated action among member organizations of the Vietnam Fatherland Front is sometimes a formality. The coordination of activities between the Vietnam Fatherland Front and the government is still "administrative". Awareness and settlement of the relationship between Party committees and grassroots organizations and the Vietnam Fatherland Front in Ho Chi Minh City still have distorted expressions. Many Party committees have not been able to do what the Party prescribes: The Party is both a member organization and a leader of the Fatherland Front. In many places, the Party committees and grassroots organizations also show signs of one-sided imposition, not respecting the autonomy, active and creative activities of the Fatherland Front. In some administrative divisions of the City, the Fatherland Front has also shown signs of disregard for the leadership of the Party committees. The City Front Working Committee's activities have sometimes been ineffective. The awareness of a part of the people about socialist democratic values has also shown deviations from the standard. Remuneration regimes and policies for cadres of the Vietnam Fatherland Front in the city have not been paid due attention; the operating budget of the Fatherland Front is still little [6]. The capacity of the Fatherland Front cadres has not met the requirements of performing their duties and responsibilities, leading to certain limitations in the operational efficiency of the Fatherland Front. These factors have affected the activities of the Vietnam Fatherland Front in establishing a socialist democracy in Ho Chi Minh City. Therefore, the study of "The role of the Fatherland Front in the process of establishing a socialist democracy in Ho Chi Minh City in the renovation period" is an urgent and meaningful issue of both theoretical and practical significance.

\section{Literature Review}

The role of the Vietnam Fatherland Front in the process of establishing a socialist democracy in the renovation period confirmed by the Platform for National Construction in the Transitional Period to Socialism (Mended and supplemented in 2011) stated: "The Vietnam Fatherland Front and people's organizations play a very important role in the cause of great unity of the whole people to build and defend the country. They represent and protect the people's legitimate rights and interests, taking care of the interests of union members and members, exercising democracy and building a healthy society, participating in the construction of the Party and State, educating revolutionary ideals and ethics, citizenship rights, and obligations, and promoting the relationship between the People, the Party and the State [7]. The position and role of the Vietnam Fatherland Front are not only affirmed in the People's awareness, in the line of the Party, but also institutionalized in the Constitution and the Law on the Vietnam Fatherland Front. Article 9 of the Constitution of the Socialist Republic of 
Vietnam (2013) defines: "The Vietnam Fatherland Front is the political alliance organization, voluntary union of political organizations, social-political organizations, prominent individuals representing their class, social stratum, ethnicity or religion and overseas Vietnamese.” [8]. The Vietnam Fatherland Front is a part of the political system of the Socialist Republic of Vietnam led by the Communist Party of Vietnam, a political base of the people's administration; expressing the will and aspirations of the people, rallying the great unity bloc of the whole people, promoting the people's mastery, consultation, coordination and unification of actions of its members, thus contributing to maintaining national independence, sovereignty, territorial integrity, successful implementation of the cause of industrialization and modernization of the country for the sake of a rich people, a strong country, a just and civilized society" [9]. The establishment of the socialist democracy of the Vietnam Fatherland Front has been demonstrated clearly at the grassroots.

The role of the Vietnam Fatherland Front in establishing socialist democracy in the renovation period at the grassroots level in Vietnam.

According to Article 17 of the Law on the Vietnam Fatherland Front, the role of the Vietnam Fatherland Front in establishing a socialist democracy, specifically and clearly, is expressed at the grassroots as follows:

Firstly, conducting public information for and mobilizing the People to implement the line and policies of the Party and policies and laws of the State. During its operation process, the Vietnam Fatherland Front and its member organizations have conducted public information and widely mobilized the People at the grassroots the line and policies of the Party, policies, and laws of the State on establishing and exercising democratic regulations at the grassroots level, and on the people's right to mastery [10]. The working people are the subject of all power; rights and obligations, dedication and enjoyment. All citizens are entitled to directly or indirectly give their opinions and proposals to competent agencies. All lines and policies of the Party, policies, and laws of the State are for the benefit of the People and with the participation of the People. That is the preeminent nature of the socialist regime in Vietnam.

Secondly, coordinating with commune-level administrations in mobilizing the People to exercise grassroots democracy and implement conventions and rules in residential areas. The mission of the Vietnam Fatherland Front is "Rallying and building a great national unity bloc, exercising democracy, and promoting social consensus". Therefore, the Fatherland Front Committee should actively and proactively coordinate with the People's Council, the People's Committee, and its member organizations to direct and organize the People so that they can exercise their citizenship rights, especially those that are directly related to the People's lives and interests in the fields of economy, culture, society, securing social order and safety.

Thirdly, directing activities of commune-level People's Inspection Boards and Community Investment Supervision Boards. The People's Inspection Board is an inspection organization of the people at the grassroots level, guided, organized, and directed by the commune-level Fatherland
Front Committee to promote the people's democratic rights, creating favorable conditions for the people's participation in State and social management. Through their activities, the People's Inspection Boards exercise the people's power to supervise all activities of State agencies and all individuals in the locality in the implementation of policies, laws, and regulations of the locals. The People's Inspection Board is not only a subject to conduct supervision and detection but also a means for the people to participate in supervision. The Community Investment Supervision Board is a form of the people's supervision, that is, the people voluntarily monitor and assess the observance of laws by the subjects under supervision; detect shortcomings and mistakes in the process of investment and construction of works; violations on investment progress and plans; violations on the process, technical regulations, categories, causing loss of property and capital; violations on waste treatment and environmental sanitation... (even for works contributed by the people) promptly report them to the provision in charge of construction for remedial action.

For the People's Inspection Boards and the Community Investment Supervision Boards to be tools for the people in communes, wards, and towns to exercise their right to supervise construction works in their localities, the Party and State have concerned and promulgated many documents specifying the responsibilities of the Fatherland Front in participating in the construction, supervision and promoting the local government, including the tasks of the People's Inspection Boards. It is the basis for the Fatherland Front at all levels to implement and guide the activities of the People's Inspection Boards and the Community Investment Supervision Boards.

Fourthly, participating in grassroots conciliation. In reconciliation work at the grassroots level, the Vietnam Fatherland Front always plays a pivotal role. Every year, the Standing Committee of the Central Committee of the Vietnam Fatherland Front guides the Vietnam Fatherland Front Committees at all levels to focus on the propagation, conducting public information and education of the law, and the implementation of grassroots reconciliation work in Vietnam [11]. The Vietnam Fatherland Front Committee and members of the Front shall coordinate with judicial agencies of the same level in promoting the propaganda and dissemination of the law on reconciliation work at grassroots to residential areas. Executing conciliation well will contribute to stabilizing social order in residential areas, facilitating authorities at all levels to strengthen social management at the grassroots, limiting lawsuits, complaints, saving time and costs of state agencies and the people.

\section{Results and Discussions}

\subsection{The Role of the Vietnam Fatherland Front in Establishing Socialist Democracy in Ho Chi Minh City During the Renovation Period}

Firstly, conducting public information for and mobilizing 
the people to implement the Party's line and policies, and the State's policies and laws. Recognizing the significance of the grassroots democracy regulation, the propaganda, and dissemination among the people about the contents of the Party's line and policies and the State's regulations on the implementation of the democratic regulation has been paid special attention by The Fatherland Front Committees at all levels of Ho Chi Minh City, considering this as a key task of the Fatherland Front's work to participate in the implementation of the grassroots democratic regulations. The Fatherland Front Committee of Ho Chi Minh city has coordinated with the government in propagating and disseminating the Party's line and the State's regulations on the implementation of the democratic regulations as follows: Plan No. 134/KH-MTTQ-BTT, dated March 18, 2020, on coordination in implementing administrative reform in the Vietnam Fatherland Front system in 2020; Plan No. 124/KHMTTQ, dated March 3, 2020, on propaganda, dissemination of the law on grassroots reconciliation; Plan No. 236/KHMTTQ-BTT, dated October 7, 2020, on the celebration of Vietnam Law Day 2020, focusing on introducing and disseminating policies, viewpoints and basic contents of the projects that have been passed and are expected to be submitted to the National Assembly for consideration or approval in 2020 and legal documents of central and local governments that have direct impacts on the people at the grassroots. The Fatherland Front system from districts to grassroots level has various forms of propaganda such as thematic reports, contests, leaflets, broadcasting on loudspeakers, and mobile radios. For example, in Go Vap District there is a model "Free legal consultation for ethnic minorities" that aims to guide the implementation of administrative procedures in many popular fields such as the declaration of birth, death, and marriage, adoption, construction permits, business registration, housing procedures, and policies related to ethnic minorities. With the coordination and guidance of the Vietnam Fatherland Front of districts and wards and the Association of Lawyers and officials of the Judicial branch, in Binh Chanh district, there are Lawyers' associations, grassroots conciliation teams cooperating with the Women's Union to establish community advisory groups (established according to hamlets and neighborhoods) to advise on legal issues arising in the residential community. In District 5, the Vietnam Fatherland Front in the district cooperates with the Department of Labor, War Invalids and Social Affairs, and the District Police to invite reporters to propagate the law for those who are reintegrated into the community and their families to understand and comply with legal provisions related to the Law on Drug Prevention and Control, basic rights and obligations of citizens, etc. (3,173 meetings were held, with 349,030 attendees). They have organized two delegations to supervise the implementation of democratic regulation at the grassroots in association with the implementation of Directive No. 19-CT/TU dated October 19, 2018, of the Standing Committee of the City Party Committee [12].

In general, the Vietnam Fatherland Front Committee of Ho
Chi Minh City has always focused on propagating and disseminating the democratic regulations, contributing to raising the awareness of law observance to the majority of the people. Some local authorities, Fatherland Front Committees, and mass organizations have developed plans to coordinate in propagating democratic regulations. Based on the contents of the democratic regulations and the guiding documents of the superiors, they have made the democratic regulations more effective, and the relationship between the government and the Fatherland Front Committee has been strengthened, thus creating conditions for the government as well as the Fatherland Front Committee to operate effectively and well perform their functions and tasks. However, the work of propagandizing and mobilizing people to implement the democratic regulations in some places is still formal, the forms of propaganda are poor; therefore, their effectiveness is not high, not attractive enough, requiring remedial measures soon.

Secondly, coordinating with the authorities at all levels to mobilize the People to exercise democracy at the grassroots level, to settle petitions and complaints of the People. The Standing Board of the Vietnam Fatherland Front has directly received 59 citizens, down 2 turns compared to the same period last year, of which there were 04 cases with large numbers of people. Lawyers participated in consulting 13 cases, mostly related to civil disputes, marriage, and family. The total number of petitions for complaints and denunciations received was 494 petitions (down 64 petitions compared to the same period last year), of which 494/494 petitions were settled, accounting for 100\%). The Board has prepared 117 official documents (including 123 petitions) to transfer them to other competent authorities for consideration and settlement; settled 66 petitions according to the regulation; persuaded the people to withdraw 01 petitions; handled three petitions according to Regulation 1374; saved 295 petitions not eligible for processing; received 19 among 117 official responses from authorities (accounting for 16.2\%). The Standing Board of the Vietnam Fatherland Front Committee of districts and grassroots has received 2,328 turns of citizens, including 114 turns with a large group of people. It has received and settled 432 among 432 petitions, accounting for $100 \%$; and received 278 among 353 official responses from authorities, representing $78.7 \%$ [12].

The number of petitions in the field of housing, land, compensation, and clearance sent to the Vietnam Fatherland Front in Ho Chi Minh City still accounts for a high rate, although they have been settled or under consideration by the competent authorities, people think that the settlement is not satisfactory or slow to give the results.

Thirdly, promoting the role of the People's Inspection Committee and the Community Investment Supervision Board in monitoring activities in the locality.

Currently, in Ho Chi Minh City, there are 319 People's Inspection Boards with a total of 2,712 members, 278 Community Investment Supervision Boards with a total of 1,946 members. In 2020, the People's Inspection Boards of communes, wards, and towns have organized 691 
supervisions focusing on the contents of the implementation, propaganda, and mobilization of the people to prevent, control and respond to the Covid-19 pandemic and the implementation of policies by the Government and the city to support the people facing difficulties due to the Covid-19 pandemic. The supervision of the People's Inspection Boards is increasingly focused, and the members of the People's Inspection Boards have made great efforts and enthusiasm in supervision activities, contributing to stabilizing security and order and building socio-economic development in the locality. At the grassroots level, the community Investment Supervision Boards have organized 556 construction supervision visits throughout the city, thereby reporting and proposing in writing about 41 works to competent divisions, People's Committees of districts, communes, wards, towns, project commanders, etc. to overcome a backlog of issues such as dust, flooding, environmental pollution, manholes collapse, water leakage incidents, etc. During the year, there have been 35 among 41 petitions considered and resolved by the authorities.

The results achieved through the activities of the People's Inspection and Community Investment Supervision Board have affirmed their prestige, position, and importance, contributing positively to the supervision of the implementation of the democratic regulations at the grassroots level. However, the role of the Fatherland Front in supervision in some establishments is still limited. For example, the qualification of some Front staff is still weak, in some places, the contents of regulations have not been fully grasped, and the roles and responsibilities of the Front have not been determined in the implementation of the democratic regulations; some contents of the people's supervision are still weak such as supervision of land use management, supervision of state projects, etc.

Fourthly, participating in grassroots conciliation.

In 2020 alone, the Standing Board of the Vietnam Fatherland Front Committee of Ho Chi Minh City has coordinated with the Department of Justice of the city to develop a joint plan to inspect the implementation of the reconciliation work at the grassroots in District 2, Hoc Mon and Binh Chanh districts. Currently, there are 1,992 mediation teams with 9,961 members. In this year, the Front has carried out 3,984 conciliation cases, of which 3,316 cases have been conciliated successfully, reaching the rate of $83.2 \%$. In general, the majority of members of the Mediation Team are members of the Fatherland Front, retired officers, enthusiastic in social activities, so they have conditions to get access and grasp the line, policies, and laws of the Government. Therefore, it should be convenient in the process of participating in the mediation of small disputes and conflicts in the community, thereby always gaining the trust of the people, contributing to limiting small cases, maintaining security and order in the residential areas.

\subsection{Discussion}

Firstly, it is necessary to continue to strengthen and renew the work of popularizing, propagating, and mobilizing the
People to exercise their right to mastery. The Vietnam Fatherland Front of Ho Chi Minh city needs to promote further propaganda of the Party's views, Ordinance No. 34/2007/UBTVQH dated April 20, 2007, of the National Assembly Standing Committee on exercising democracy in communes, wards, and towns, Decree No. 71/1998/ND-CP dated September 8, 1998, of the Government, promulgating the regulation on exercising democracy in the operation of the agencies; direction of the city Party Committee on the regulation on grassroots democracy to raise the awareness of cadres, civil servants, public employees, political awareness of the people's right to mastery, creating a strong change in awareness and responsibility of both the political system and the whole society, in which it is necessary to raise the awareness and responsibility of the heads.

Secondly, it is essential to exercise grassroots democracy and reform administrative procedures. The Ho Chi Minh City Fatherland Front needs to regularly review, remove or propose competent authorities to abolish administrative procedures that are no longer appropriate in the direction of simplifying administrative procedures to create favorable conditions for the people and businesses. It should well perform the publicity and transparency of finance, regimes, policies, and personnel work. The form of publicity should be diverse and flexible under the situation of the unit to ensure all information is accessible to cadres, civil servants, and public employees. The Vietnam Fatherland Front of the city should regularly review organizational regulations, operational regulations, working regulations, and other relevant regulations to promulgate, amend and supplement them following the law. At the same time, it should well implement the contents and forms of publicity under the provisions of the Prime Minister's Decision No. 05/2014/QDTTg dated January 15, 2014, on publicizing related regimes and policies to the means, working conditions, and treatment regime of the Party and State for cadres, civil servants and public employees so that the people can contribute opinions and supervise through the activities of the People's Inspection Committee or units assigned to inspect at agencies, units or organizations.

Third, it is necessary to strengthen inspection and supervision of the exercise of the Grassroots Democracy Regulation. The Ho Chi Minh City Fatherland Front needs to promote the implementation of the patriotic emulation movement linking the exercise of the Grassroots Democracy Regulations with the government's mass mobilization work and the campaign "Study and follow the example of Ho Chi Minh's morality"; implementing the Resolution of the 4th Session of the Party Central Committee, term XI on many urgent issues in the building of the Party in the current situation; coordinating to well implement the joint program on building new rural areas. It should periodically review, summarize and draw experience; praise and reward agencies, units, and individuals that well exercise the Regulation on democracy at the grassroots level.

Fourthly, strengthening the coordination between the Fatherland Front and the authorities and member 
organizations in the exercise of democratic regulation.

To well exercise the grassroots democracy regulation, it is necessary to build an effective coordination mechanism between the Fatherland Front and mass organizations and other organizations in the political system. The People's Committees of districts should direct the People's Committees of wards, communes, and towns to continue implementing Ordinance No. 34/2007/PL-UBTVQH dated April 6, 2007, of the National Assembly Standing Committee on exercising democracy in communes, wards, and towns, focusing on monitoring the exercise of democratic regulation at the grassroots level. The contents of the democratic regulation must be publicized to the people such as policy, compensation plan, support for settlement site clearance, resettlement, infrastructure construction, adjustment plans, residential area planning, funds to mobilize people's contributions; well-performing the work of receiving citizens, promptly and effectively solving the legitimate grievances of the people; strengthening dialogue and direct contact with people in residential quarters and hamlets. The form of publicity must be rich and diverse, and the public place must be convenient for people to follow, to avoid public posting of expired, old, and torn documents.

In the context of complicated developments in the world and the region, there are both many opportunities and challenges; however, the socio-economic situation of our country in general and Ho Chi Minh City, in particular, have achieved important achievements; our prestige and position have increasingly raised. 2020 is a special year, with many outstanding milestones recorded with important contributions from Ho Chi Minh City Fatherland Front Committees at all levels. For instance, the people of Ho Chi Minh city have appreciated the achievements made in the year 2020 and term $\mathrm{X}$. The public opinion welcomes the city's initiative and leadership in smart city construction, notably promoting technology application in administrative procedures. The cadres, Party members and the people support and accompany the Party Committees, government, Fatherland Front, mass organizations in performing socio-economic development tasks, ensuring national defense and security; caring for policy families, poor households, and people in difficult circumstances; especially supporting people in difficulty due to the impact of the Covid-19 pandemic and the people suffering from natural disasters. However, facing the challenges of the renewing process, requires the staff of the Vietnam Fatherland Front at the grassroots in Ho Chi Minh City to continue to make efforts, promote responsibility, overcome limitations, promptly advise the Party Committees to lead, direct and actively coordinate with the authorities, branches and mass organizations in the city to effectively implement the programs of the Fatherland Front, especially in the exercise of the democratic regulation.

\section{Conclusion}

Promoting the strength of the great national unity is the responsibility of the whole political system, but the Vietnam
Fatherland Front in Ho Chi Minh City plays a very important role in establishing a socialist democracy in the city in the renovation period. The specific conclusions are as follows:

Well performing the consolidation and strengthening of the great national unity bloc; tightening the relationship between the people, the Party, and the State, thus contributing to creating a high consensus in society; encouraging the people to promote their rights; actively participating in the building of the Party and a clean and strong government; closely maintaining close contact with the people, contributing to the establishment of socialist democracy in Ho Chi Minh City in the period of renovation period. The Vietnam Fatherland Front plays a very important role in creating the people's great unity bloc, promoting the people's right to mastery, conducting consultations, and coordinating and unifying actions among its members in the cause of national construction and defense.

In the cause of national renewal with a growing democracy, the role of the Vietnam Fatherland Front and mass organizations has been increasingly important. The Front has the noble task of rallying and building the great unity bloc of the whole people, strengthening political and spiritual consensus among the people. During the renovation period, the Vietnam Fatherland Front has strengthened the rally and mobilization of the people; promoting the people's patriotism, national pride, will to self-reliance; uniting all Vietnamese at home and abroad, regardless of social class, ethnicity, religion, belief, past, ideology, and political opinion, as long as they agree with the renovation process, to gain the goals of maintaining independence, sovereignty, unity, and territorial integrity, successfully realizing the cause of industrialization and modernization of the country for the sake of a prosperous people, a strong, democratic, equitable, and civilized country.

The Ho Chi Minh city Fatherland Front has increasingly promoted its role in representing and protecting the people's legal and legitimate rights and interests; meeting the requirements of being the political basis of the people's administration; being able to carry out supervision and social criticism; participating in building the Party and the State; being as the core of rallying and uniting all patriotic Vietnamese people, creating social consensus and trust among the people; promoting democratic values; making a worthy contribution to the cause of national renewal, construction and development.

\section{References}

[1] Hoang Chi Bao (2012). From innovative practice to new theoretical awareness of socialism in Vietnam 1986-2011. Hanoi: National Political Publishing House.

[2] Tran Dinh Hoan (editor) (2008), Perspectives and principles on reforming the political system in Vietnam in the period 2005 - 2020. Hanoi: National Political Publishing House.

[3] Nguyen Duc Binh (2012), The theory of revolution and development of Vietnam. Hanoi: National Political Publishing House, Hanoi. 
[4] Ngoc Loi Pham \& Phuong Khanh Vo (2021). The Role of the Government's Mass Mobilization in Stabilizing the People's Situation in the Districts of Ho Chi Minh City Today, International Journal of Humanities Social Sciences and Education (IJHSSE) Volume 8, Issue 3.

[5] Ho Chi Minh City Party Committee, (2020). Document of the 11th Party Congress of the city, term 2020 - 2025, HCMC: General Publishing House.

[6] The report summarizing the results of 10 years of implementing Decision No. 290-QD/TW dated February 25, 2010 of the Politburo (Xth term) and Decision No. 489QD/TU dated July 16, 2011 of the Standing Committee of Ho Chi Minh City Party Committee on the Regulation on mass mobilization work of the political system.

[7] The Communist Party of Vietnam (2011). Document of the 11th National Party Congress of Deputies, Publishing House. Hanoi: National Political Publishing House, p. 86.
[8] National Assembly of the Socialist Republic of Vietnam (2020). Constitution of the Socialist Republic of Vietnam. Hanoi: National Politics -Truth Publishing House.

[9] National Assembly (2015). Law on the Vietnam Fatherland Front. Hanoi: National politics Publishing House.

[10] Nguyen Tho Anh (2012). Performing the functions of social monitoring and criticism of the Vietnam Fatherland Front today. Hanoi: National Political Publishing House.

[11] Pham Ngoc Quang, (2018). "Promoting democracy in the condition of one ruling party". New theoretical and practical issues posed in the current situation. Central Theory Council. Hanoi: National Political Publishing House.

[12] Vietnam Fatherland Front Committee of Ho Chi Minh City. Summary Report on the Front work in 2020, December 30, 2020. 